Article

\title{
Vintage Urban Planning in Italy: Land Management with the Tools of the Mid-Twentieth Century
}

\author{
Bernardino Romano *(D), Francesco Zullo®, Alessandro Marucci and Lorena Fiorini $₫$ \\ Department DICEAA, University of L'Aquila, 67100 L'Aquila, Italy; francesco.zullo@univaq.it (F.Z.); \\ alessandro.marucci@univaq.it (A.M.); lorena.fiorini@graduate.univaq.it (L.F.) \\ * Correspondence: bernardino.romano@univaq.it
}

Received: 6 September 2018; Accepted: 6 November 2018; Published: 9 November 2018

\begin{abstract}
This paper describes a critical situation for Italy, which is one of the causes of the overall disorganization of settlement growth in the past decades. Using the data extracted from some institutional databases, we show that a large part of the national territory is managed with highly effective decision-making tools (such as municipal town planning schemes in Italy), which are, however, lagging behind in their conception and fulfilment of scientific, cultural, and political requirements deemed essential today for effective and sustainable land transformation. Municipalities with plans dating back to a quarter of a century ago, or without any plans, are 1445 in number (17\% of the total) and involve 6,200,000 ha of territory ( $1 / 5$ of Italy) with almost 10 million residents. The territorial changes in these geographical areas, mainly concentrated in the south, are managed with tools based on mid-20th century concepts and techniques, although a large proportion of these territories are demographically active and transform substantial portions of land. Thus, for at least 15-20 years, these territories underwent transformations disconnected from town plans and driven essentially by one-off measures or managed through numerous exceptional and negotiated procedures provided for by national legislation. Today, it seems necessary for southern Italy to overcome its extensive delay in territorial planning, and the drive can only come from national government. This would help it finally respond to current environmental sustainability, risk resilience, and territorial security requirements, through appropriate and technically advanced management procedures not envisaged in previous planning procedures.
\end{abstract}

Keywords: planning tools; sustainable urban planning; urban growth; land take; land-use change

\section{Introduction}

This paper contains the results of research on the update of Italian municipal planning. The research made use of institutional data available on the web and produced by the National Institute of Urban Planning (INU). The main objective of our work was to show that a large part of the national territory is managed with highly effective decision-making tools (such as municipal town planning schemes in Italy), which are, however, lagging behind in their conception and fulfilment of scientific, cultural, and political requirements deemed essential today for effective and sustainable land transformation.

Italian urban planning legislation, both at the national and regional level, does not establish when municipal planning tools should be updated. Therefore, their contents, defined at a given historical time, can theoretically remain unchanged for decades, regardless of social, technological, and economic changes in areas. This paper illustrates both the extreme lack of homogeneity and the homogeneity of the national territory, resulting from the historical updating of the fundamental and almost exclusive tools through which land transformation of all sorts and at every level is determined in Italy. 
A different conduct was adopted by other European countries, such as France, Germany, and Great Britain, which, since the 1970s, implemented national planning policies and enacted legislation favoring strategic approaches to planning é [1-4]. In these countries, there is vertical/hierarchical supervision of decisions concerning land transformation, construction, and infrastructure (very similar to what is theoretically in place in Italy since 1942) that, however, is enforced more strictly and is actually more efficient.

In France, there was profound reorganization [5,6] from the 1970s to 2017, aimed at setting up inter-municipal associations that manage the Schéma de la Cohérence Territoriale (SCOT), that in turn monitors the municipal Plan Local d'Urbanisme (PLU). According to Gibelli [7], "there is not the slightest opportunity for privates to propose urban transformation/regeneration projects derogating from the urban development plans in force and involving simplified approval procedures ... and all the various, unlikely stories and neologisms used to reward real estate finance over the past decades in Italy".

As of 1965, the reorganization of the regulations concerning "regional planning" (Raumordnungsgesetz) was initiated in Germany, and was later further improved in 1975 ("General Regional Planning Program for the Federal Territory" (Raumordnungsprograrmme fur die gross raumige Entwicklung des Bundesgebiet) [8-10]. Franco Archibugi stated over forty years ago [11] that "this is a complex system of highly integrated 'cascading' plans (despite some differences in name and structure due to the legislative autonomy of the Länder), in an orderly sequence of further specifications that make them particularly efficient. From this standpoint, an 'institutional framework' could not be more operational and, thus, more effective. This is visible 'to the naked eye' when traveling through the country, owing to the visual perception of great order and supervision achieved in the territorial development of Germany".

In 1971, the regulation of territorial matters in Great Britain was initiated, in order to assure a vertically and horizontally integrated process in all planning activities [12-14]. The actual spatial planning level provided by the "institutional framework", which was reorganized and made more functional by the 1971 Act, is that of "counties" which are the most important local organization agencies having broad administrative autonomy. There are over 60 counties in Great Britain that draw up structure plans that are submitted mandatorily to the central authorities for approval (the Department for the Environment), and are fully fledged integrated territorial, socio-economic, and physical planning documents. The subsequent levels of spatial planning concern "districts" (of which there are 93) [15] that each county is broken down into, and that may draw up three types of plans-the District Plan (development and land use), the Action Area Plan (urban renewal), and the Subject Plan (sectoral development). The county authorities draft the Development Plan schemes, and the close links between local plans and structure plans maintain the important vertical integration of territorial planning, while the structure plans assure horizontal integration.

We limited our overview to three European countries; however, the experiences of an orderly, and even more thorough and effective "institutional framework" can also be found in the Netherlands, Belgium, Denmark, and Sweden [16,17].

To this regard, it should be recalled that, in Italy, national and regional legislation provides for a "hierarchical" planning procedure at different spatial/administrative levels. As a result, local plans have to take into account the indications of higher level plans, as in France, Germany, and Great Britain. However, unlike these countries, higher-level planning never really played a key role in influencing lower-level decision-making, since Italian municipalities enjoy the utmost autonomy in the management of transformations of all kinds, with practically no superordinate strategic control. This condition gradually grew over several decades amidst general indifference, but only recently was its pathological side noticed: unjustified over-urbanization that is very disorganized, extremely energy-hungry, and at odds with public interest regarding environmental and urban quality $[18,19]$.

This system of territorial planning, lacking in strategic level, does not even provide for any form of coordination between the plans of municipalities that might introduce social and political transparency 
in planning before transformations actually occur. In the present-day situation, it is basically impossible to understand what will happen in a given territory beyond the geographical dimension of individual municipalities. Likewise, it is impossible to assess, in advance, land consumption or the environmental damage that may occur during the timeframe of municipal plans.

Moreover, it is well known that, although Italian historical centers preserve significant landscape and architectural quality, recognized and appreciated worldwide, the urban settlements created over the past 50 years probably have on average the worst distribution, construction, and aesthetic features in Europe. It is certainly true that the Italian urban planning law of 1942 (Law No. 1150, dated 17 August 1942) was one of the first and most innovative laws, as it introduced planning at various levels and urban plans extended to the entire municipal territories limiting building activities in municipalities lacking urban plans. However, it is also true that much of this invaluable content, including the option of public expropriation in areas of expansion, was either never implemented or was implemented in ways that lost their regulatory strength over the decades [20]. After 1942, Italy no longer enacted national laws on urban planning or land transformation. Starting from the 1970s, all legislative activity in the field was delegated to the 20 regions in the country. Although very intensive over time, this activity was characterized by strong heterogeneity and weak strategic regulation, thus easing forms of control and increasingly delegating decision-making to municipalities, however small and demographically irrelevant they may be [21-23].

Indeed, reports by eminent and far-sighted academics regarding the inefficiency of Italian urban planning were published as early as the 1980s; however, unfortunately, almost all literature produced is in Italian and, thus, in our references, we had to include many titles that may be difficult to consult [24-26].

\section{Data and Methods}

The data used were extracted from national reports drafted periodically by the National Institute of Urban Planning (INU), which include a general update of municipal planning tools. The section used in this work is the one updated in 2016 [27] with the five timeframes of < 1995, 1995-2000, 2000-2010, post 2010, and "no plan". The data come from surveys carried out in each region on existing plans, and the timeframes used provide rather effective information. For the category more subject to ambiguity (pre-1995), other previously processed data were used [28,29] highlighting municipalities that adopted plans well before the 1990s or even the 1980s. The picture we obtained is of a very heterogeneous set of territories encompassing many that, even today, are trying to govern themselves using tools of over 40 years ago. To this regard, an emblematic case is the municipality of L'Aquila, the capital of the Abruzzi region that, despite the destructive events caused by the 2009 earthquake, keeps on managing its territory with an urban plan dating back to 1975 and drawn up on paper.

In the Italian geographical partition, we used the traditional historical structure with all the regions belonging to the Kingdom of Naples before the unification of Italy in the south and those forming the Papal States and Tuscany in central Italy.

\section{Results}

The data on the frequency with which Italian municipal plans are updated have a very strong geographical latitudinal connotation, clearly visible in Figures 1 and 2. There is a clear "peninsula effect", whereby the southern part of the country, excluding a few minor exceptions, systematically uses older urban tools dating back to the first half of the last century (before 1995) and even earlier. The only exception is Sardinia where most plans were drawn up after 2000, while Lazio is more comparable to the south. The more northern Italian areas show a marked difference, with most of the plans drafted between 2000 and 2010 and, in some cases, such as Lombardy, Trentino, and Veneto, after 2010. In the absence of national legislation regulating the frequency with which municipal planning tools are updated, the only reason for this clear difference in the updating of tools to control land transformation is regional and local sensitivity toward territorial planning, in addition to local 
economic conditions perhaps. Again, Figure $2 b, c$ show that this macro geographical distribution can also be extended to the percentages of territory and population having fairly constant proportionality. Other available data (Figures 3 and 4) show that, in Italy, there are still municipal plans drafted well before 1995, and even dating back to 1968 and earlier. Hence, 500,000 ha of national territory and the corresponding 500,000 inhabitants still fall under the action of plans drafted half a century ago, while a total of 2,500,000 people living in an area of over one million hectares (a medium-sized Italian region) have their territory "managed" with tools updated between 1969 and 1977—an almost archaic historical period in terms of sociology, economy, culture, and needs of life!

If we focus our attention on plans dating back to over 25 years ago, the municipalities with plans prior to 1995 , or without any plans, number 1445 (17\% of the total) and involve $6,200,000$ ha of territory ( $1 / 5$ of Italy). In these areas, there are almost 10 million inhabitants, $17 \%$ of the total population, with an average per capita income of $€ 14,700$ ( $86 \%$ of the national value). As shown in Figure 5, the demographic trend was incremental in all three geographical areas considered over the past 60 years (in particular central and northern Italy), while population density is slightly lower than the national average, with 161 inhabitants $/ \mathrm{km}^{2}$. Moreover, municipalities with older plans are generally demographically smaller, but, at least in central and southern Italy, have population growth rates that are very similar to those of municipalities with plans implemented after 1995.

The way in which older municipal plans are distributed by latitude is described below.

There are 300 municipalities in the North, covering 1,000,000 ha and with about 1,000,000 inhabitants; 215 municipalities in central Italy covering 1,200,000 ha and with 1,800,000 inhabitants; and lastly, 921 municipalities in southern Italy, covering 4,300,000 ha with 6,700,000 inhabitants. Within these municipalities, there are $1,144,568$ ha of protected areas $(20 \%$ of the Italian total), with 20 national parks covering 685,000 ha, in addition to 1,171,401 ha of Natura 2000 sites ( $24 \%$ of the Italian total).

From 2012 to 2016, $203 \mathrm{~km}^{2}$ were urbanized in Italy [30] (ISPRA, 2016) and, in municipalities with pre-1995 plans, land uptake for urban use amounted to $38 \mathrm{~km}^{2}$-equal to about $20 \%$ of the total. Of these, only $2 \mathrm{~km}^{2}$ are found in municipalities with pre-1968 plans, $12 \mathrm{~km}^{2}$ approximately in municipalities with plans drawn up between 1969 and 1977, and $9.5 \mathrm{~km}^{2}$ in municipalities with plans drawn up between 1978 and 1984, while about $40 \%$ of the total is land belonging to municipalities with plans which were drawn up between 1985 and 1995. An interesting fact is that municipalities with pre-1968 plans had minimal, yet hardly negligible, urban dynamics (500 ha per year) compared to the others.

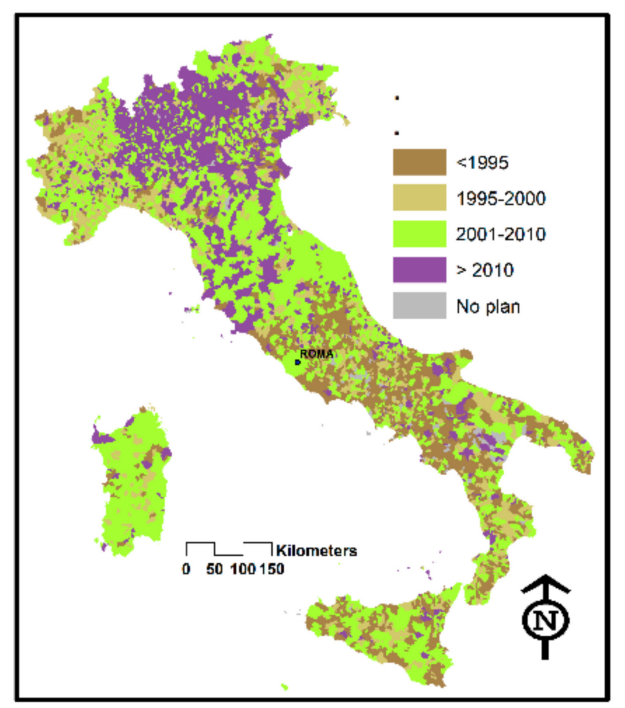

Figure 1. Geographical distribution of plan update thresholds (re-processing of National Institute of Urban Planning (INU) 2016 data). 


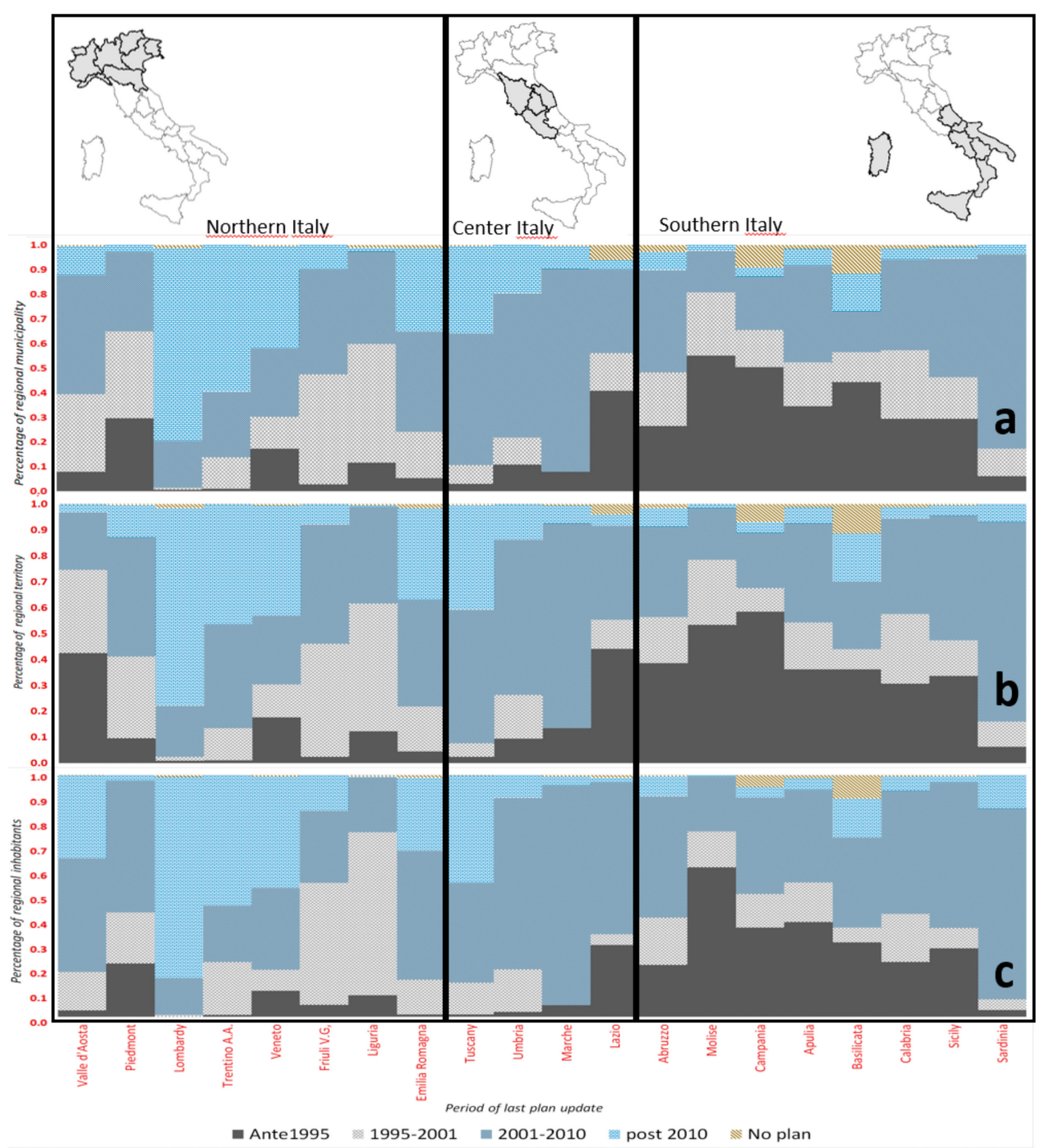

Figure 2. Percentages of regional territories affected by municipal planning broken down per updating periods of urban planning tools (re-processing by the authors of INU 2016 data). From the top: (a) regional territory; (b) regional municipalities; (c) regional population.

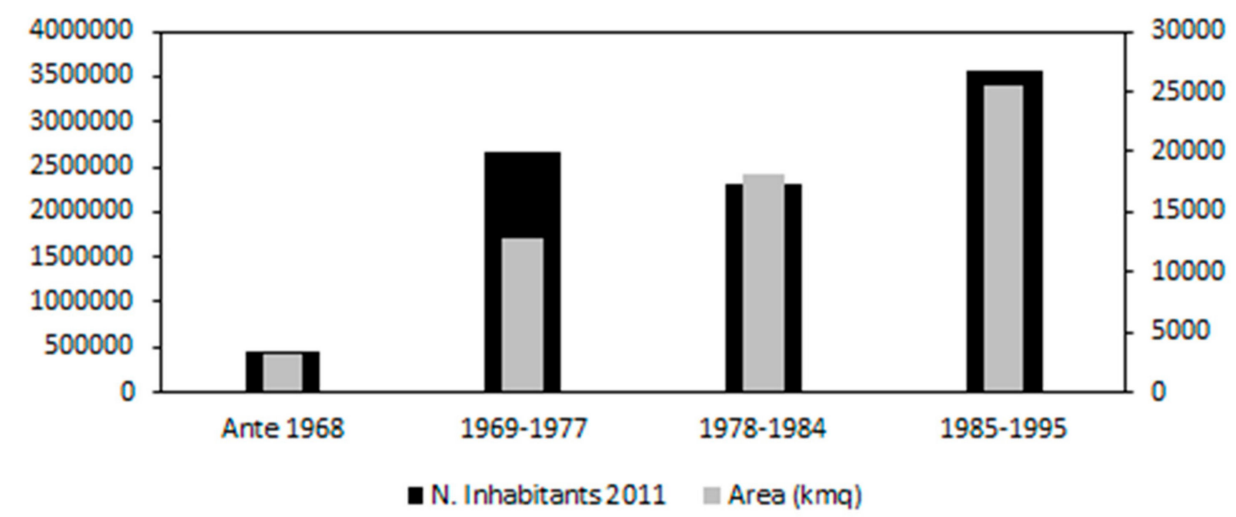

Figure 3. Territorial areas and population affected by urban planning tools in the pre-1995 timeframes (re-processing of INU data 2005, 2007). 


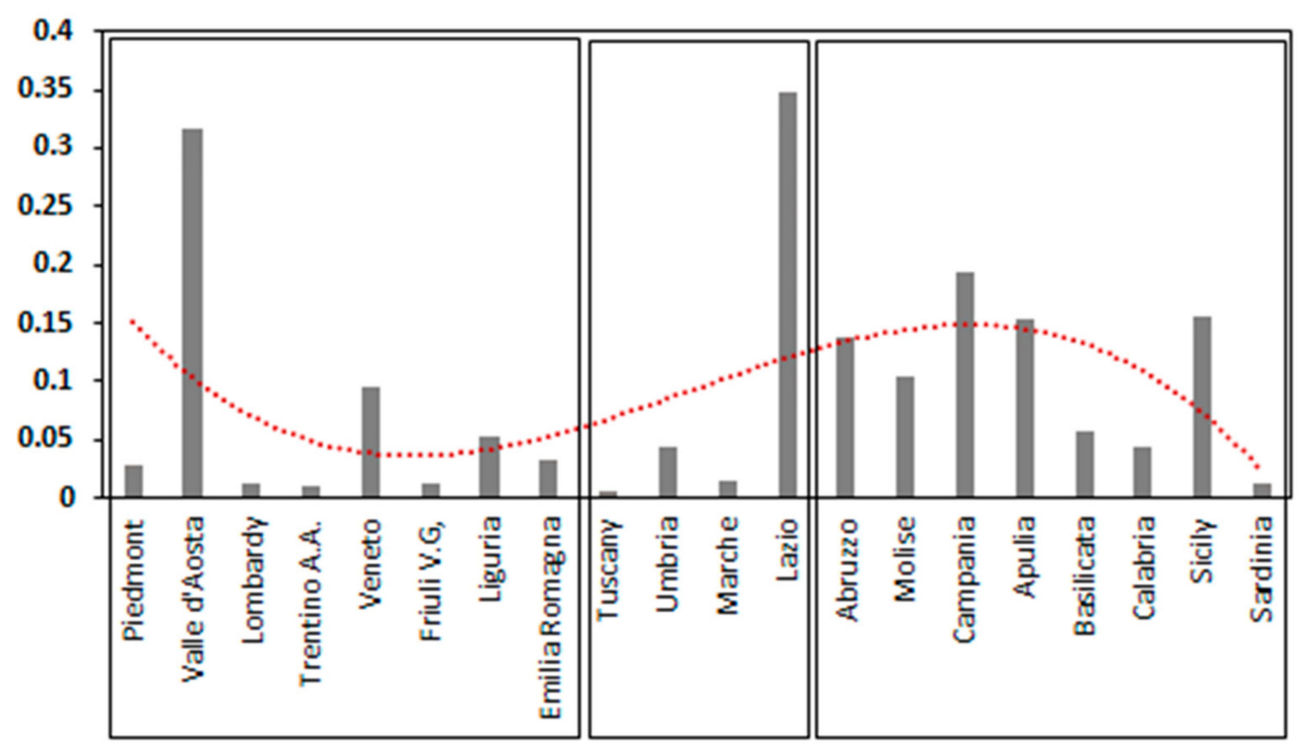

Figure 4. Portions of regional territories affected by urban plans dating back to over 25 years ago.
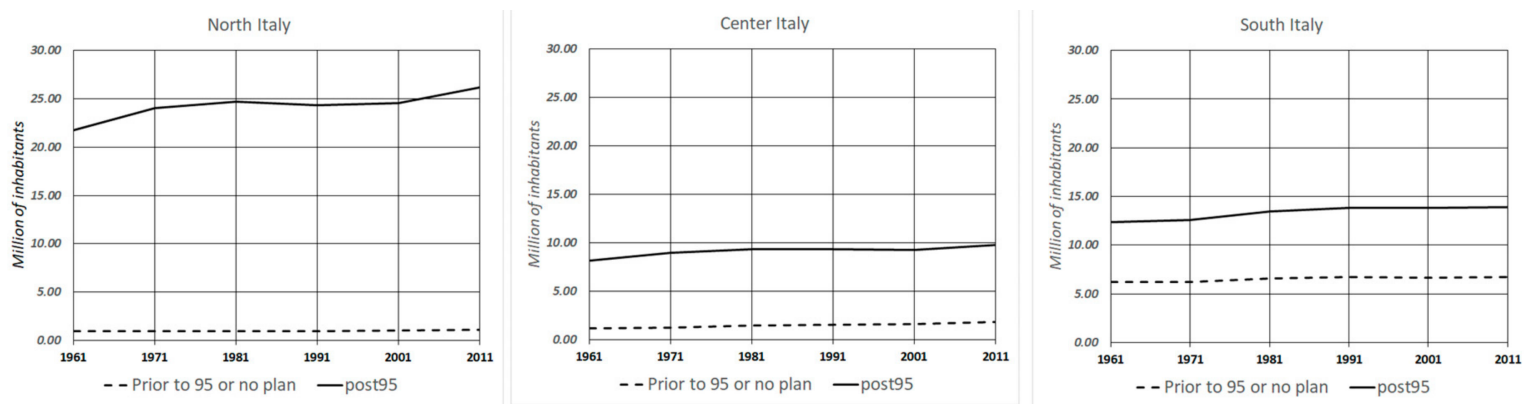

Figure 5. The demographic dynamics of Italian municipalities with urban plans prior to 1995 or no plans, and post 1995, in the decades from 1961 to 2011.

About 560 municipalities, among the 1445 analyzed, had positive demographic dynamics from 1991 to 2011 , with an average of $+17 \%$ and a median of $12 \%$, while over 80 municipalities exceeded a $30 \%$ population increase. These 560 municipalities have about six million inhabitants with, on average, over 10,000 inhabitants each. Over half of them have a population exceeding 5000 inhabitants that, by Italian standards, is an appreciable demographic level considering urban planning dynamics. They cover 200,000 ha of urbanized land (10\% of the Italian total) and had an increase in excess of $400 \%$ since the 1950 s [19]. The total area covered by these municipalities is around $2,500,000$ ha $(8 \%$ of the Italian territory).

\section{Changes and New Legislation after 1995}

In the 25 years since the closing of the over 1400 old municipal plans mentioned earlier, fundamental changes occurred in terms of legislation, technology, and scientific-cultural concepts that profoundly influenced recent municipal planning, both internationally/nationally and regionally. Table 1 summarizes some of the key phases that occurred after 1995 and led to radically different ways of dealing with municipal plans, changing their drafting criteria and processing methodology, and adding contents that were unthinkable in the mid-20th century. 
Table 1. Chronological thresholds for the introduction of laws, directives, concepts, and techniques related to land planning. GIS-geographic information system; PC-personal computer.

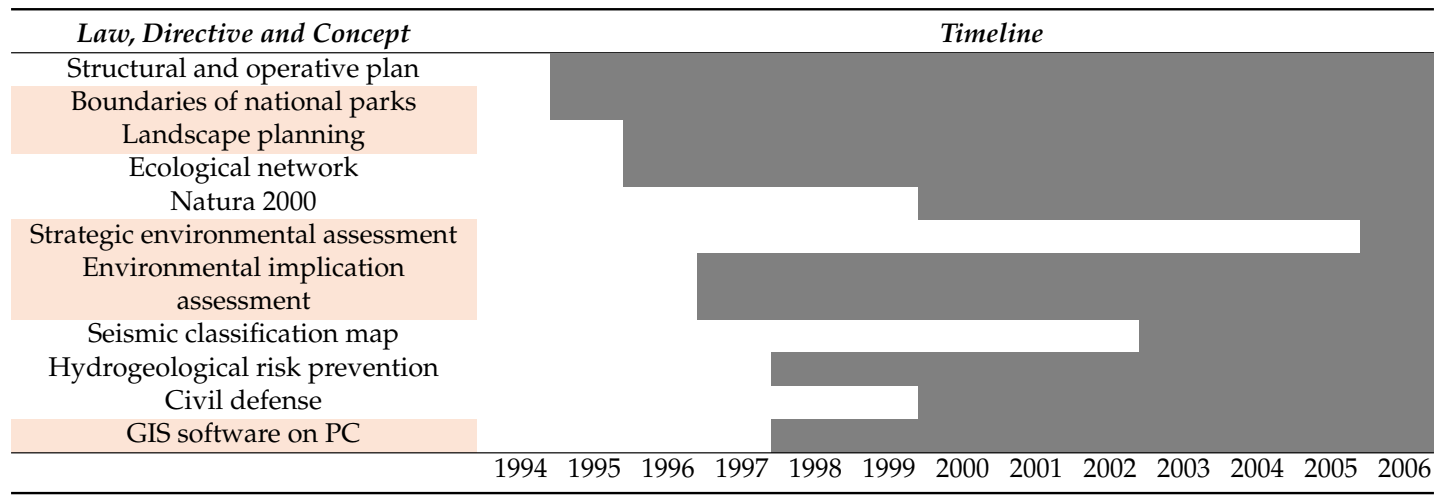

Starting from the environmental regulatory framework, the framework law on protected areas 394/91 was approved recently; however, more specifically, the boundaries of parks and related protection rules were established in Presidential Decree dated 5 June 1995. Practically no Italian park had a plan, excluding the Gran Paradiso park and, as mentioned earlier, municipalities with old plans cover $1,144,568$ ha of protected areas ( $20 \%$ of the Italian total) with 20 national parks covering 685,000 ha, of which only six existed prior to the framework law. The situation concerning landscape planning is somewhat more positive. Until 1995, only eight landscape plans pursuant to the Galasso law (no. 431/85) were approved by the regions [28] and these did not include Lazio and the more southern regions where plans are very old and were approved between 1996 and 2003.

In the mid-1990s, however, there were no territorial policies on ecosystems and biodiversity in place, and only with the Ministerial Decree enacted on 3 April 2000 was a first national list of "sites of community importance and special protection areas drawn up, identified pursuant to Directives 92/43/EEC and 79/409/EEC" [31]. Although the "Regulation Implementing Directive 92/43/EEC on the conservation of natural and semi-natural habitats and wild fauna and flora" was issued in Presidential Decree no. 357/97, only the Ministerial Decree approved on 3 September 2002, established the "guidelines for the management of Natura 2000 sites" to support related management plans. The same environmental networks, as a concept applied to spatial planning, appeared for the first time in Italian scientific literature only in 1996 [32,33]; hence, previously approved plans could not take them into account.

Even mandatory environmental assessments, currently an important part of the activities of public bodies with regards to planning, were not yet provided for by Italian law in 1995. The Strategic Environmental Assessment (SEA), now an essential procedure accompanying every territorial plan and program, was introduced in the European Community by Directive 2001/42/EC of the European Parliament and Council dated 27 June 2001 [34]. Member states were supposed to transpose this directive by 21 July 2004. Italy failed to comply with this deadline and transposed this directive in the second part of Legislative Decree no. 152 dated 3 April 2006 that came into force on 31 July 2007. The foregoing decree was substantially amended and supplemented by Legislative Decree no. 4 dated 16 January 2008, which came into force on 13 February 2008 and again was amended by Legislative Decree no. 128 dated 29 June 2010.

Similar considerations apply to the Environmental Impact Assessment, provided for by the "Habitat Directive" (92/43/EEC) since 1992, but introduced in Italian law only through Presidential Decree no. 357 dated 8 September 1997, later amended by Presidential Decree no. 120 dated 12 March 2003.

Many Italian municipalities are situated in high seismic risk areas and over one-third (36\%) of those having old plans are located in areas defined as risk 3 and 4 by Prime Minister's Decree no. 3274/2003, updated by Prime Minister's Order no. 3519 dated 28 April 2006, and concern over two million hectares, i.e., $37 \%$ of municipal areas with old plans. To this regard, seismic categories 
(three categories applied only to about 3000 municipalities, equal to $45 \%$ of the national territory) were identified on the basis of several Ministerial Decrees passed between 1981 and 1984, and then revised in 1998 (Legislative Decree no. 112, art. 94, paragraph 2a). The provisions relating to Technical Standards for buildings that regulated building activities prior to 2003 referred to the Ministerial Decree of 1975, later replaced by another Ministerial Decree in 1996 [35].

Then, there was a further update following the review of building sector legislation, and Presidential Decree no. 380 was enacted in 2001 encompassing the anti-seismic provisions of Law no. 64 of 1974.

Again, in terms of hydrological and hydrogeological risk, legislation in this field was enacted after 1995. Only in 1998, after the disaster in Sarno, was Law no. 267 dated 3 August 1998 passed for the "Conversion into law and amendment of legislative decree no. 180 dated 11 June 1998, containing urgent measures for hydrogeological risk prevention and in favor of areas affected by landslides in the Campania region". Civil protection functions were established significantly by Law no. 365 dated 11 December 2000: "Conversion into law and amendment of Legislative Decree no. 279 dated 12 October 2000, concerning urgent actions in areas at very high hydrogeological risk, in the field of civil protection and in favor of areas in the Calabria region damaged by the hydrogeological disasters of September and October 2000".

From the standpoint of methodological structure, after 1995, the physiognomy of municipal plans changed, since regional laws provided for the separate drafting of the "structural" plan and the "operating" plan [36], introducing very different elements compared to the previous conventional form from the standpoint of political action and the legal-applicative framework. Previous plans were based on the criteria of the only Italian national planning law of 1942. Figure 6 [37] shows that most regional planning laws were enacted or updated well after 1995 almost throughout the country.

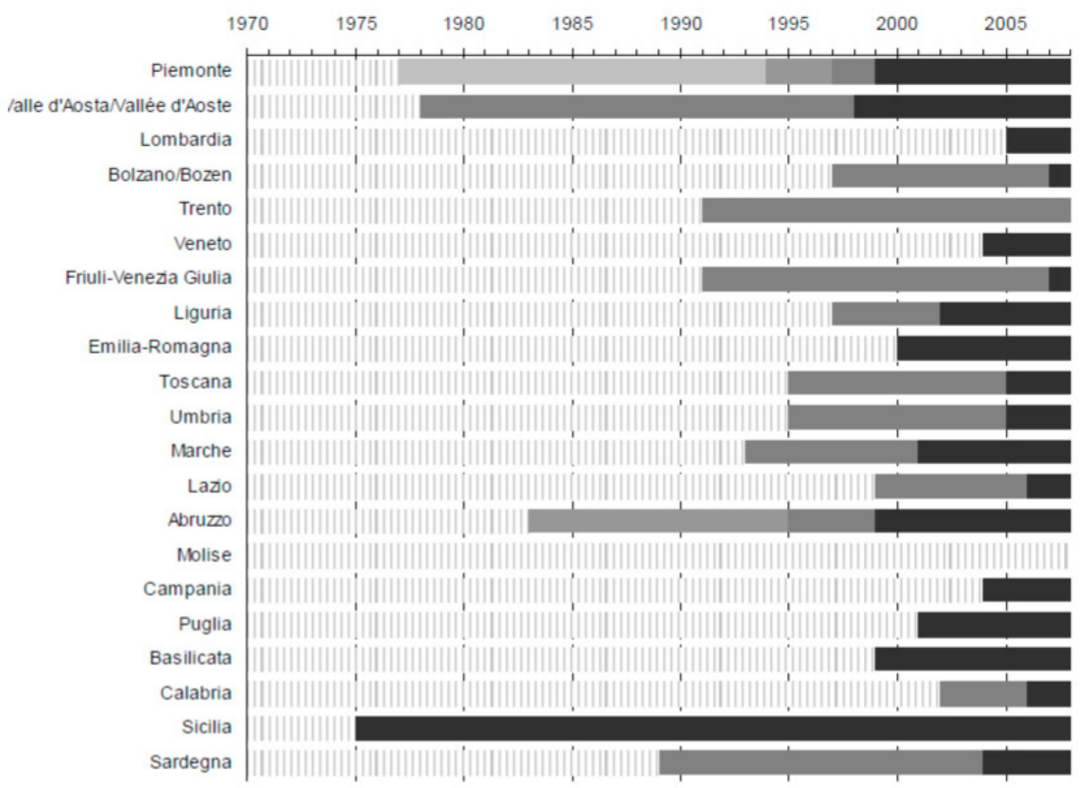

Figure 6. Periods of application of regional urban laws in 1970-2008 (the darker color indicates more recent legislation, including amendments and supplements) [37].

The first regional reform law (RL) was the one passed in Tuscany (RL no. 5 dated 16 January 1995, territorial governance rules). Later, almost all regions tried innovating respective municipal planning systems, even in the absence of specific references to a national law establishing principles in this field. This led to a variety of jargons that have nothing to do with the recognition of the legislative autonomy of regions, but are the product of the different approaches of law-makers who often fail to understand that the main purpose of planning is to determine land use and conform property to this end, leading to the application of rules that need to have specific legal significance $[38,39]$. 
The Structural Plan is a long-term, non-prescriptive plan. It sets out the strategic guidelines for territorial governance deriving from the Territorial Coordination Plan (PTC; provincial), supplemented by the development guidelines expressed by the local community. It does not create new constraints, but incorporates them from higher-level plans (PTCs, regional environmental landscape plans, etc.). Its duration is fixed at the time of its adoption.

The Operating Plan is a working and prescriptive plan, with a limited duration (term of office of the municipal council). It consists of a timeline for the Structural Plan to select the priority actions to be implemented during the term of office of the municipal council and to identify the funds needed for their execution at the time of its adoption.

Furthermore, it is very important to mention the events that occurred in the past 25 years, for which the mid-20th century marks a threshold from a technological perspective, which, for planning, led to a profound revolution impacting all its phases: surveying, drafting, participation, management, and revision. Geographic information system (GIS) software, installable on the desktops of many professional firms became established around 1997-1998, concomitantly with more efficient versions of the Windows operating system, while previously they were only available to some regional or public offices and installed on dedicated machines. Thus, the plans completed prior to 1995 were drafted mostly using computer-aided design (CAD) software, in the versions already in use for architecture and less suitable for territorial applications, if not in archaic paper form.

\section{Discussion}

This paper describes a critical situation for Italy, which is one of the main causes of the overall disorganization of settlement growth in the past decades. Basically, on the one hand, municipal plans constitute the only decision-making level for land transformation; on the other, they fail to perform this function adequately, since they are not updated in accordance with regulatory, technological, and cultural requirements and innovation over the years. This is also due to the cumbersome methodology used to draft plans; taking ten years to set up a plan is not uncommon in Italy, while five years is the standard. Therefore, while an urban planning tool is being produced, huge changes may occur in the territory, making it substantially obsolete when approved. As a result, a paradoxical gap is created between the content of the plan and the territorial reality it is meant to govern, with ensuing inevitable implementation issues often overcome by means of "improvised" urban practices that may even be quite disconnected from actual problems.

The analyzed data show that $1 / 5$ of the Italian territory, with almost 10 million inhabitants $(17 \%$ of the total population) is managed with tools based on mid-20th century concepts and techniques, although a large proportion of these areas are demographically active and transform substantial portions of land. Of course, owing to the enormous complexity of the data, we do not have information on the numerous variations of pre-1995 plans that may have partially offset or remedied their shortcomings; this is surely how the boundaries of parks and Natura 2000 sites were fixed and the management plans of Sites of Community Interest (SCIs) and protected areas devised. However, it is far more unlikely that the old general town planning schemes took into account environmental networks that are an initial information layer that should condition the entire framework of a municipal plan. Likewise, it is also highly unlikely that they introduced an efficient SEA process, as this is an accompanying evaluation procedure that, in the case of all plans, is designed to support the tool along its entire development and management process. Therefore, it cannot easily be included in an old tool that already produced a large part of its effects in a decade of application (1995-2005). The use of environmental impact assessments (EIAs) is easier as they refer to actions directly or indirectly involving Natura 2000 sites. As they were introduced in Italian legislation in 1997, it is highly likely that old plans took them into consideration. Similar considerations apply to risks, at least hydrogeological risks, and civil protection. Relevant rules were adopted between 1998 and 2000 and, thus, it is possible that the plans nearer the 1995 threshold may have taken them into account before their contents were substantially implemented. Clearly, the same reasoning does not apply to seismic risk, given that the 
most advanced standards were adopted in 2003, when the plans in question were in force for about a decade and, therefore, already produced many effects without these indications.

Lastly, it is quite possible that these old plans were drawn up based on the 1942 law, without a structural-operating framework. It is quite certain that at least those nearer 1995 were drafted using CAD software, while many are on paper support. These aspects seriously impair their active management, monitoring, revision, transferability, and interaction with other planning tools adopted subsequently in the digital GIS format.

Through the term "disorganization", we intend to classify all those phenomena that, in the last 25 years, were considered pathological for the quality, sustainability, and social benefits of territories and cities. Until the mid-1990s, the Italian urban planning and political culture viewed plans as mere urban growth and land rent tools. This sort of management produced planning behaviors that fail to consider the actual functions of services, their costs, and territorial security, from the standpoint of the environment, nature, and risks. Until this historical period, the real estate market was still very active and fostered sustained and economically viable real estate output. Following 2010, this trend declined, and the plans adopted thereafter focused little on urban growth, because the market was slowing down, and also the European directives and ensuing national laws aiming at the sustainability of transformations started producing their effects. Today, it is not easy to say whether more recent plans (following 2010) produced more "organized" territories, because not enough time has elapsed (less than eight years) to assess their effects, which we can certainly do in the next $5-10$ years. It is, however, true that recent plans responded to significant cultural conditioning and, above all, mandatory environmental rules and assessments, which will certainly make them land transformation tools that are more sensitive to present-day social and environmental issues.

\section{Conclusions}

The previous considerations on inefficiency apply mostly to plans drafted well before 1995, but are at any rate applicable also to all those drafted before that year. We can, therefore, claim with some credibility that, for at least 15-20 years, the territories governed by these tools underwent transformations disconnected from any urban plans, and were driven essentially by one-off measures or managed by means of numerous exceptional and negotiated procedures provided for by national law. It is not easy to formulate a proposal for action to tackle the issues described in this paper, but it seems necessary for southern Italy to overcome its extensive delay in territorial planning, and the drive can only come from national government. The difficulties that this geographical area of the country shows in all sectors—social, educational, cultural, economic, and infrastructural—are certainly tied to the widespread disregard for planning. Moreover, national and international investment is surely discouraged, given the lack of updated plans fulfilling all present-day environmental sustainability, risk resilience, and territorial security requirements, through appropriate and technically advanced management procedures. The "peninsula effect", clearly caused by old municipal plans, is geographically too evident to think that it may depend on random factors and not on the historic "delay" that became an unwritten Italian rule in many sectors. These concluding considerations certainly cannot cover all the issues and causes that led to the current situation (economic, social, cultural, and obviously regulatory). However, it is probably true that, in southern Italy, political sensitivity toward "effective" planning is, on average, lower than in other geographical areas of the country, and above all more heterogeneous in the various southern regions. Will the solution to the aforementioned problems be reached only by the territorial bodies that plan (regions and municipalities)? It seems unlikely given the results obtained to date. A suggestion that emerges from the analysis set out in this paper is that of fostering the undeniable role of the state in promoting "modern" and updated planning in a geographical area of the country that desperately needs it. This may involve a coordinating role for regions and municipalities that must be encouraged and helped to reconfigure their territorial programs according to the latest scientific and technological requirements, in order to bridge the gap with the most advanced areas of the country. 
Author Contributions: Conceptualization, B.R. Data curation, F.Z. Methodology, L.F. Software, A.M. Supervision, B.R. Writing—original draft, B.R.

Funding: This research received no external funding.

Acknowledgments: The methodology presented has been implemented in the research project and monitoring supported by Umbria Region, that we want to thank. The indicators used have been developed within the SUNLIFE project (LIFE 13/NAT/IT/000371-Strategy for the Natura 2000 Network of the Umbria Region). We are grateful to Cheryl Di Lorenzo for her collaboration.

Conflicts of Interest: The authors declare no conflicts of interest.

\section{References}

1. Newman, P.; Thornley, A. Urban Planning in Europe: International Competition, National Systems, and Planning Projects; Routledge: New York, NY, USA, 1996; p. 277. ISBN 0-203-42794-7.

2. Healey, P.; Williams, R. European urban planning systems: Diversity and convergence. Urban Stud. 1993, 30, 701-720. [CrossRef]

3. Naess, P. Urban planning and sustainable development. Eur. Plan. Stud. 2001, 9, 503-524. [CrossRef]

4. Couch, C.; Sykes, O.; Börstinghaus, W. Thirty years of urban regeneration in Britain, Germany and France: The importance of context and path dependency. Prog. Plan. 2011, 75, 1-52. [CrossRef]

5. John, P.; Cole, A. Urban regimes and local governance in Britain and France: Policy adaption and coordination in Leeds and Lille. Urban Aff. Rev. 1998, 33, 382-404. [CrossRef]

6. Weber, C. Interaction model application for urban planning. Landsc. Urban Plan. 2003, 63, 49-60. [CrossRef]

7. Gibelli, M.C. In Italia, ci Pensa il Mercato; Invece, in Francia i Piani Urbanistici Diventeranno Intercomunali! Carte in Regola. 2018. Available online: http://www.carteinregola.it/index.php/i-piani-urbanistici-infrancia-e-in-italia/ (accessed on 19 July 2018).

8. Wiegandt, C. Urban development in Germany: Perspectives for the future. GeoJournal 2000, 50, 5-15. [CrossRef]

9. Pauleit, S.; Duhme, F. Assessing the environmental performance of land cover types for urban planning. Landsc. Urban Plan. 2000, 52, 1-20. [CrossRef]

10. Schmidt, S.; Buehler, R. The Planning Process in the US and Germany: A Comparative Analysis. Int. Plan. Stud. 2007, 12, 55-75. [CrossRef]

11. Archibugi, F. La Pianificazione Territoriale: La Funzionalità del Quadro Istituzionale ai Vari Livelli. In Proceedings of the $2^{\circ}$ Congresso National di Architettura: Politiche Edilizie e Urbanistiche in Italia; IN/ARCH, Istituto National di Architettura: Roma, Italy, 1981. Available online: http://www. francoarchibugi.it/pdf/81-11-\%20La\%20pianificazone\%20territ...pdf (accessed on 12 June 2018).

12. Cullingworth, J.B.; Nadin, V. Town and Country Planning in the UK; Routledge: New York, NY, USA, 2006; p. 573. ISBN 0-415-35809-4.

13. Sager, T. Neo-liberal Urban Planning Policies: A Literature Survey, 1990-2010. Prog. Plan. 2011, 76, 147-199. [CrossRef]

14. Lord, A.; Tewdwr-Jones, M. Is planning "Under Attack"? Chronicling the deregulation of urban and environmental planning in England. Eur. Plan. Stud. 2014, 22, 345-361. [CrossRef]

15. EUROSTAT. Regions in the European Union. Nomenclature of Territorial Units for Statistics NUTS 2006/EU-27; European Commission: Luxembourg, 2007.

16. Abrantes, P.; Fontes, I.; Gomes, E.; Rocha, J. Compliance of land cover changes with municipal land use planning: Evidence from the Lisbon metropolitan region (1990-2007). Land Use Policy 2016, 51, 120-134. [CrossRef]

17. Tiana, L.; Lib, Y.; Yanc, Y.; Wangc, B. Measuring urban sprawl and exploring the role planning plays: A Shanghai case study. Land Use Policy 2017, 67, 426-435. [CrossRef]

18. Romano, B.; Zullo, F.; Fiorini, L.; Ciabò, S.; Marucci, A. Sprinkling: An Approach to Describe Urbanization Dynamics in Italy. Sustainability 2017, 9, 97. [CrossRef]

19. Romano, B.; Zullo, F.; Fiorini, L.; Marucci, A.; Ciabò, S. Land transformation of Italy due to half a century of urbanisation. Land Use Policy 2017, 67, 387-400. [CrossRef]

20. Brenna, S. A Cinquant'Anni Dalla Mancata Riforma Sullo: La Strana Disfatta Dell'Urbanistica Pubblica; Blecic, I., Ed.; Lo Scandalo Urbanistico 50 Anni Dopo; F. Angeli: Milan, Italy, 2017; pp. 69-76.

21. Ave, G. Urban Land and Property Markets in Italy; UCL Press: London, UK, 1996; p. 206. ISBN 9781857280531. 
22. Gabellini, P. Profiles of Italian urban planning. PLANUM 2008, 17, 1-15.

23. Colavitti, A.M.; Usai, N.; Bonfiglioli, S. Urban Planning in Italy: The Future of Urban General Plan and Governance. Eur. Plan. Stud. 2012, 21, 167-186. [CrossRef]

24. Salzano, E. (Ed.) La Città Sostenibile; La città sostenibile, Edizione delle Autonomie: Roma, Italy, $1992 ;$ p. 445.

25. Gibelli, M.C.; Salzano, E. (Eds.) No Sprawl; Alinea: Firenze, Italy, 2006.

26. Balducci, A.; Fareri, P. Consensus-Building, Urban Planning Policies, and the Problem of Scale: Examples from Italy. In Participation and the Quality of Environmental Decision Making. Environment E Policy; Coenen, F.H.J.M., Huitema, D., O'Toole, L.J., Eds.; Springer: Dordrecht, The Netherlands, 1998; Volume 14, pp. 163-178.

27. INU. Rapporto dal Territorio 2016; INU: Rome, Italy, 2017; p. 367. ISBN 9788876031625.

28. INU. Rapporto dal Territorio 2005; INU: Rome, Italy, 2006; p. 268. ISBN 8876030123.

29. INU. Rapporto dal Territorio 2007; INU: Rome, Italy, 2008; p. 407. ISBN 8876030123.

30. ISPRA. Dissesto Idrogeologico in Italia: Pericolosità e Indicatori di Rischio—Rapporto 2015; ISPRA: Rome, Italy, $2015 ;$ p. 162. ISBN 978-88-448-0751-1.

31. European Commission. Natura 2000: Protecting European Biodiversity; European Commission: Brussels, Belgium, 2008; p. 292. ISBN 9789279083082.

32. Malcevschi, S.; Bisogni, L.; Gariboldi, A. Reti Ecologiche ed Interventi di Miglioramento Ambientale; Il verde editoriale: Milan, Italy, 1996.

33. Romano, B. Oltre i Parchi, la Rete Verde Regionale; DAU, Università dell'Aquila, Andromeda: Teramo, Italy, 1996; p. 80. ISBN 88-86728-20-4.

34. Fischer, T.B. Theory and Practice of Strategic Environmental Assessment; Earthscan: London, UK, 2017 ; p. 181. ISBN -13:978-1-84407-453-2.

35. Peruzza, L.; Pessina, V. Zone Sismiche e Pericolosità in Italia: Dalle Norme Regionali alla Comunicazione del Rischio. Earth-prints 1/2016; 2016; pp. 15-31. Available online: http:/ /hdl.handle.net/2122/10366ISSN: 1722-0025 (accessed on 27 June 2018).

36. Sartorio, F.S. Strategic spatial planning: A historical review of approaches, its recent revival, and an overview of the state of the art in Italy. Plan. Rev. 2005, 41, 26-40. [CrossRef]

37. Costanzo, L. Alcune evidenze sullo stato della pianificazione territoriale in Italia. In Proceedings of the Atti XXXI Conferenza Italiana di Scienze Regionali, Aoste, Italy, 20-22 September 2010.

38. Falco, L. Le riforme possibili, le proposte dell'INU per la legislazione urbanistica a partire dalla formazione della legge del 1942. Urban. Quad. 1995, 6, 159-170.

39. De Santis, F. (Ed.) Il Governo del Territorio in Toscana alla luce del Testo Unico; Commento alla 1.r. Toscana n.1/2005; Giuffrè: Milan, Italy, 2005; p. 914. ISBN 9788814120343. 